\title{
Antimicrobial Activity of Oleanolic Acid on Listeria monocytogenes under Sublethal Stresses of $\mathrm{NaCl}$ and $\mathrm{pH}$
}

\author{
Yohan Yoon and Kyoung-Hee Choi ${ }^{1}{ }^{1 *}$ \\ Department of Food and Nutrition, Sookmyung Womens's University, Seoul 140-742, Korea \\ ${ }^{1}$ Department of Oral Microbiology, College of Dentistry, Wonkwang University, Iksan 570-749, Korea
}

\begin{abstract}
The objective of this study was to evaluate the inhibition of Listeria monocytogenes growth by oleanolic acid under sublethal stresses of $\mathrm{NaCl}$ and $\mathrm{pH}$. L. monocytogenes ATCC15313 (6 $\log \mathrm{CFU} / \mathrm{mL})$ was inoculated in microplate wells containing brain heart infusion (BHI) broth supplemented with oleanolic acid in various amounts $(0,0.25,0.5,1.0,1.5,2.0$, and 4.0 $\mu \mathrm{g} / \mathrm{mL})$, and different $\mathrm{pHs}(5$ and 7$)$ and $\mathrm{NaCl}$ concentrations $(0,3$, and $6 \%$ ), followed by incubation under accelerated storage condition $\left(37^{\circ} \mathrm{C}, 48 \mathrm{~h}\right)$. The optical density (OD) of the samples was measured at $0,6,12,24$, and $48 \mathrm{~h}$ at $600 \mathrm{~nm}$. After the lag phase duration was observed at the early stage of incubation, the OD values of $L$. monocytogenes significantly increased $(p<0.05)$ in $\mathrm{BHI}$ broth formulated with 0 and $3 \%$ of $\mathrm{NaCl}$ during accelerated storage at $\mathrm{pH} 5$ and 7 . However, the growth of L. monocytogenes in $6 \% \mathrm{NaCl}$ and at less than $0.5 \mu \mathrm{g} / \mathrm{mL}$ of oleanolic acid had no growth at $\mathrm{pH} 5$ and only gradual growth at $\mathrm{pH}$ 7. Moreover, L. monocytogenes generally had lower OD values as the concentrations of oleanolic acid increased. As expected, the OD values of L. monocytogenes were generally higher $(p<0.05)$ at $\mathrm{pH} 7$ than at $\mathrm{pH}$. These results indicate that oleanolic acid should be useful in inhibiting the growth of L. monocytogenes.
\end{abstract}

Key words: oleanolic acid, Listeria monocytogenes, ready-to-eat meat, phytochemical

\section{Introduction}

Various antimicrobials have been used to ensure that manufactured foods remain safe and unspoiled, and most preservatives commonly used in food industry today are mainly from synthetic chemicals, but their safety problems have been receiving growing attention (Feng et al., 2010). Thus, various phytochemicals from a variety of plants known to have antimicrobial activity have been examined to control foodborne pathogens (Lee et al., 2007; Ros and Recio, 2005; Tassou et al., 2000; Valero and Salmeroj, 2003). Plants synthesize various aromatic substances, including many antimicrobial phytochemicals such as phenols and their oxygen substituted derivatives, essentials oils, terpenes and alkalids (Kurek et al., 2010). Oleanolic acid are triterpenoid compounds isolated from foods, medical herbs, and various other plants in free form or bound to glycosides (Somova et al., 2003). Oleanolic acid has shown anti-inflammatory (Ovesna et al.,

*Corresponding author: Kyoung-Hee Choi, Department of Oral Microbiology, College of Dentistry, Wonkwang University, Iksan 570-749, Korea. Tel: 82-63-850-6911, Fax: 82-63-8507313, E-mail: kheechoi@wku.ac.kr
2004), antiallergic (Banno et al., 2004), hepatoprotective (Liu, 1995), antimicrobial (Ngouela et al., 2005) and antiulcer (Ovesna et al., 2004) activities, and also exert an antiparasitic activity to Trypanosoma spp. (Cunha et al., 2003) and Leishmania spp. (Torres-Santos et al., 2004).

Listeria monocytogenes is a ubiquitous psychrotrophic pathogen causing listeriosis with high fatality rate (up to $30 \%$ ), and it survives and grows at low $\mathrm{pH}$ as well as in high salt content (Farber and Peterkin, 1991; VazquezBolland et al., 2001). Nunez de Gonzalez et al. (2004) suggested that most L. monocytogenes contamination on ready-to-eat meat and poultry products occurs after processing. In the United States, foodborne illness caused by L. monocytogenes has been estimated at 2,493 infections and 499 deaths annually (Mead et al., 1999). Even though most ready-to-eat meat and poultry products may contain various antimicrobials such as sodium chloride, nitrite and lactate/diacetate salts to inhibit L. monocytogenes growth, their effectiveness may vary due to type of product and other factors (Glass et al., 1989; Mbandi and Shelef, 2002). In addition, most consumers have recently concerned about use of the chemicals and also synthesized chemicals in processed meat because of their safety problems. Thus, novel antimicrobials especially from 
plants to inhibit L. monocytogenes growth in ready-to-eat meat and poultry products may be appropriate to improve consumer acceptance to the products.

This study evaluated the antimicrobial activity of oleanolic acid on inhibition of L. monocytogenes growth under sublethal stresses of $\mathrm{NaCl}$ and $\mathrm{pH}$.

\section{Materials and Methods}

\section{Preparation of inoculum}

L. monocytogenes ATCC15313 was activated in $5 \mathrm{~mL}$ of brain heart infusion (BHI) broth (Becton Dickinson, $\mathrm{MD}$, USA) for $24 \mathrm{~h}$ at $37^{\circ} \mathrm{C}$. Stationary phase cells were serially diluted in phosphate buffered saline (PBS, $\mathrm{pH}$ 7.4; $0.2 \mathrm{~g}$ of $\mathrm{KH}_{2} \mathrm{PO}_{4}, 1.5 \mathrm{~g}$ of $\mathrm{Na}_{2} \mathrm{HPO}_{4} \cdot 7 \mathrm{H}_{2} \mathrm{O}, 8.0 \mathrm{~g}$ of $\mathrm{NaCl}$, and $0.2 \mathrm{~g}$ of $\mathrm{KCl}$ in 1 liter of distilled water) to obtain approximately $6 \log \mathrm{CFU} / \mathrm{mL}$.

\section{Experimental design}

The effects of $\mathrm{pH}$ (5 and 7) adjusted solely with $1 \mathrm{~N}$ $\mathrm{HCl}$, oleanolic acid concentrations $(0,0.25,0.5,1,1.5,2$, and $4 \mu \mathrm{g} / \mathrm{mL}$; Sigma-Aldrich Corp., MO, USA), and three levels $(0,3$, and $6 \%)$ of $\mathrm{NaCl}$ (Junsei Chemical Co., Ltd., Japan) on inhibition of L. monocytogenes growth in BHI broth were evaluated. This resulted in a total of 42 combinations in a complete factorial design.

\section{Inoculation and microbiological analysis}

Each combination was placed in wells of 96 micro plate, and L. monocytogenes was inoculated in each well to obtain $4 \log \mathrm{CFU} / \mathrm{mL}$. Oleanolic acid stock solution $(60 \mu \mathrm{g} / \mathrm{mL})$ was prepared in dimethyl sulfoxide (SigmaAldrich) and added to each well to obtain 0, 0.25, 0.5, 1, $1.5,2$, and $4 \mu \mathrm{g} / \mathrm{mL}$. The micro plates were incubated under accelerated condition $\left(37^{\circ} \mathrm{C}, 48 \mathrm{~h}\right)$, which is an appropriate condition to confirm antimicrobial resistance of pathogenic bacteria to antimicrobials and full recovery of the injured pathogens (Oh et al. 2004). The OD (Optical density) values of the samples were measured at 0,6 , 12,24 , and $48 \mathrm{~h}$ at $600 \mathrm{~nm}$ with spectrophotometer (Spectra Max250, Molecular Devices, USA).

\section{Statistical analysis}

This study was repeated twice with two samples in each replicate. A complete factorial design ( $\mathrm{pH}$ [5 and 7] $\times$ oleanolic acid $[0,0.25,0.5,1,1.5,2$, and $4 \mu \mathrm{g} / \mathrm{mL}] \times$ $\mathrm{NaCl}[0,3$, and 6\%]) was used in this study. The OD values in interactions among $\mathrm{pH}$, oleanolic acid, and $\mathrm{NaCl}$ concentrations were analyzed by the mixed model procedure of SAS ${ }^{\circledR}$ version 9.2 (SAS Institute, Cary, NC, USA), and random effects in the model was removed at alpha $=0.05$ by the forward stepwise method with type III F-test. All least squares mean comparisons among the interactions were performed with the pairwise $t$-test at alpha $=0.05$.

\section{Results and Discussion}

The OD values of L. monocytogenes in BHI broth prepared with different concentrations of $\mathrm{NaCl}$ and different levels of oleanolic acid at $\mathrm{pH} 5$, which is simulating readyto-eat meat and poultry related condition, are shown in Tables 1-3. After lag phase duration was observed at early stage of incubation, the optical density of L. monocytogenes significantly increased $(p<0.05)$ in BHI broth $(\mathrm{pH} 5)$ supplemented only with $0 \%$ and $3 \%$ of $\mathrm{NaCl}$ and $0-2 \mu \mathrm{g} /$ $\mathrm{mL}$ of oleanolic acid during accelerated storage, but no growth $(p \geq 0.05)$ of the pathogen was observed in BHI broth plus $6 \%$ of $\mathrm{NaCl}$ at all concentrations of oleanolic acid (Tables 1-3). This result indicates that when $\mathrm{NaCl}(0-$ $6 \%$ ) was combined with oleanolic acid, the antimicrobial activity of oleanolic acid on the pathogen was synergistically increased. Moreover, L. monocytogenes had lower OD values as oleanolic acid concentration increased (Tables 1-3). Inhibited growth of L. monocytogenes may be related to impaired peptidoglycan metabolism caused by oleanolic acid because the triterpenoids of oleanolic acid may influence the enzymes related to peptidoglycan metabolism such as the proteins involved in cell wall synthesis, hydrolysis and modification which might decrease peptidoglycan cross-linkage and thus enhance its susceptibility to mutanolysin, an $\mathrm{N}$-acetylmuramidase (Kurek et al., 2010).

A study by Horiuchi et al. (2007) showed that oleanolic acid inhibited even growth of methicillin-resistant Staphylococcus aureus and vancomycin-resistant enterococci. On this wise, antimicrobial activities of the phytochemicals extracted from various plants have been studied to control antibiotic resistant bacteria. Mycobacterium tuberculosis is the bacteria causing tuberculosis with very high mortality rate in world wide because this pathogen is resistant to multiple drugs, but oleanolic acid extracted from Lantana hispida (Verbenacease) inhibited M. tuberculosis growth (Jimenez-Arellanes et al., 2007). Use of the extract from mulberry leaves also inhibited biofilm formation of Streptococcus mutans, which is one of the causes related to antibiotic resistance (Islam et al., 2008). They suggested that the continuous studies to examine 
Table 1. Optical density of Listeria monocytogenes ATCC15313 at $600 \mathrm{~nm}$ under sublethal stresses of oleanolic acid and $0 \%$ of $\mathrm{NaCl}$ at pH 5 during incubation at $37^{\circ} \mathrm{C}$ for $48 \mathrm{~h}$

\begin{tabular}{|c|c|c|c|c|c|}
\hline \multirow{2}{*}{$\begin{array}{l}\text { Oleanolic acid } \\
\qquad(\mu \mathrm{g} / \mathrm{mL})\end{array}$} & \multicolumn{5}{|c|}{ Incubation time $(\mathrm{h})$} \\
\hline & 0 & 6 & 12 & 24 & 48 \\
\hline 0 & $0.000 \pm 0.000^{\mathrm{Ac}}$ & $0.007 \pm 0.002^{\mathrm{Ac}}$ & $0.009 \pm 0.001^{\mathrm{Ac}}$ & $0.077 \pm 0.002^{\mathrm{Ab}}$ & $0.106 \pm 0.011^{\mathrm{Aa}}$ \\
\hline 0.25 & $0.000 \pm 0.000^{\mathrm{Ac}}$ & $0.006 \pm 0.001^{\mathrm{Ac}}$ & $0.008 \pm 0.001^{\mathrm{Ac}}$ & $0.057 \pm 0.002^{\mathrm{Bb}}$ & $0.087 \pm 0.008^{\mathrm{Ba}}$ \\
\hline 0.5 & $0.000 \pm 0.000^{\mathrm{Ac}}$ & $0.007 \pm 0.002^{\mathrm{Ac}}$ & $0.008 \pm 0.001^{\mathrm{Ac}}$ & $0.055 \pm 0.006^{\mathrm{Bb}}$ & $0.084 \pm 0.011^{\mathrm{Ba}}$ \\
\hline 1 & $0.000 \pm 0.000^{\mathrm{Ac}}$ & $0.008 \pm 0.002^{\mathrm{Ac}}$ & $0.008 \pm 0.002^{\mathrm{Ac}}$ & $0.034 \pm 0.007^{\mathrm{Cb}}$ & $0.082 \pm 0.011^{\mathrm{Ba}}$ \\
\hline 1.5 & $0.000 \pm 0.000^{\mathrm{Ac}}$ & $0.007 \pm 0.002^{\mathrm{Ac}}$ & $0.009 \pm 0.001^{\mathrm{Ac}}$ & $0.023 \pm 0.002^{\mathrm{Db}}$ & $0.073 \pm 0.004^{\mathrm{Ca}}$ \\
\hline 2 & $0.000 \pm 0.000^{\mathrm{Ab}}$ & $0.006 \pm 0.002^{\mathrm{Ab}}$ & $0.009 \pm 0.002^{\mathrm{Ab}}$ & $0.009 \pm 0.001^{\mathrm{Eb}}$ & $0.058 \pm 0.008^{\mathrm{Da}}$ \\
\hline 4 & $0.000 \pm 0.000^{\mathrm{Aa}}$ & $0.007 \pm 0.001^{\mathrm{Aa}}$ & $0.008 \pm 0.001^{\mathrm{Aa}}$ & $0.009 \pm 0.001^{\mathrm{Ea}}$ & $0.007 \pm 0.001^{\mathrm{Ea}}$ \\
\hline
\end{tabular}

A-E: Means within a column with different superscripts are significantly different $(p<0.05)$

${ }^{\mathrm{a}-\mathrm{c}}$ : Means within a row with different superscripts are significantly different $(p<0.05)$

Table 2. Optical density of Listeria monocytogenes ATCC15313 at $600 \mathrm{~nm}$ under sublethal stresses of oleanolic acid and $3 \%$ of $\mathrm{NaCl}$ at pH 5 during incubation at $37^{\circ} \mathrm{C}$ for $48 \mathrm{~h}$

\begin{tabular}{|c|c|c|c|c|c|}
\hline \multirow{2}{*}{$\begin{array}{l}\text { Oleanolic acid } \\
(\mu \mathrm{g} / \mathrm{mL})\end{array}$} & \multicolumn{5}{|c|}{ Incubation time $(\mathrm{h})$} \\
\hline & 0 & 6 & 12 & 24 & 48 \\
\hline 0 & $0.000 \pm 0.000^{\mathrm{Aa}}$ & $0.007 \pm 0.002^{\mathrm{Ab}}$ & $0.008 \pm 0.001^{\mathrm{Ab}}$ & $0.013 \pm 0.003^{\mathrm{ABb}}$ & $0.095 \pm 0.008^{\mathrm{Aa}}$ \\
\hline 0.25 & $0.000 \pm 0.000^{\mathrm{Ac}}$ & $0.007 \pm 0.002^{\mathrm{Ac}}$ & $0.009 \pm 0.001^{\mathrm{Ac}}$ & $0.019 \pm 0.005^{\mathrm{Ab}}$ & $0.073 \pm 0.005^{\mathrm{Ba}}$ \\
\hline 0.5 & $0.000 \pm 0.000^{\mathrm{Ac}}$ & $0.009 \pm 0.001^{\mathrm{Ac}}$ & $0.009 \pm 0.001^{\mathrm{Ac}}$ & $0.018 \pm 0.001^{\mathrm{Ab}}$ & $0.070 \pm 0.006^{\mathrm{Ba}}$ \\
\hline 1 & $0.000 \pm 0.000^{\mathrm{Ab}}$ & $0.009 \pm 0.001^{\mathrm{Ab}}$ & $0.010 \pm 0.001^{\mathrm{Ab}}$ & $0.014 \pm 0.003^{\mathrm{ABb}}$ & $0.067 \pm 0.006^{\mathrm{Ba}}$ \\
\hline 1.5 & $0.000 \pm 0.000^{\mathrm{Ab}}$ & $0.009 \pm 0.001^{\mathrm{Ab}}$ & $0.009 \pm 0.001^{\mathrm{Ab}}$ & $0.011 \pm 0.000^{\mathrm{ABb}}$ & $0.068 \pm 0.004^{\mathrm{Ba}}$ \\
\hline 2 & $0.000 \pm 0.000^{\mathrm{Ab}}$ & $0.007 \pm 0.002^{\mathrm{Ab}}$ & $0.008 \pm 0.000^{\mathrm{Ab}}$ & $0.010 \pm 0.005^{\mathrm{Bb}}$ & $0.051 \pm 0.014^{\mathrm{Ca}}$ \\
\hline 4 & $0.000 \pm 0.000^{\mathrm{Aa}}$ & $0.008 \pm 0.002^{\mathrm{Aa}}$ & $0.009 \pm 0.002^{\mathrm{Aa}}$ & $0.009 \pm 0.001^{\mathrm{Ba}}$ & $0.010 \pm 0.003^{\mathrm{Ca}}$ \\
\hline
\end{tabular}

A-C. Means within a column with different superscripts are significantly different $(p<0.05)$

${ }^{\mathrm{a}-\mathrm{b}}$ : Means within a row with different superscripts are significantly different $(p<0.05)$

Table 3. Optical density of Listeria monocytogenes ATCC15313 at $600 \mathrm{~nm}$ under sublethal stresses of oleanolic acid and $6 \%$ of $\mathrm{NaCl}$ at pH 5 during incubation at $37^{\circ} \mathrm{C}$ for $48 \mathrm{~h}$

\begin{tabular}{|c|c|c|c|c|c|}
\hline \multirow{2}{*}{$\begin{array}{l}\text { Oleanolic acid } \\
\qquad(\mu \mathrm{g} / \mathrm{mL})\end{array}$} & \multicolumn{5}{|c|}{ Incubation time (h) } \\
\hline & 0 & 6 & 12 & 24 & 48 \\
\hline 0 & $0.000 \pm 0.000^{\mathrm{Aa}}$ & $0.007 \pm 0.001^{\mathrm{Aa}}$ & $0.008 \pm 0.002^{\mathrm{Aa}}$ & $0.008 \pm 0.001^{\mathrm{Aa}}$ & $0.006 \pm 0.001^{\mathrm{Aa}}$ \\
\hline 0.25 & $0.000 \pm 0.000^{\mathrm{Aa}}$ & $0.007 \pm 0.001^{\mathrm{Aa}}$ & $0.008 \pm 0.001^{\mathrm{Aa}}$ & $0.008 \pm 0.001^{\mathrm{Aa}}$ & $0.007 \pm 0.002^{\mathrm{Aa}}$ \\
\hline 0.5 & $0.000 \pm 0.000^{\mathrm{Aa}}$ & $0.007 \pm 0.001^{\mathrm{Aa}}$ & $0.008 \pm 0.001^{\mathrm{Aa}}$ & $0.009 \pm 0.001^{\mathrm{Aa}}$ & $0.008 \pm 0.002^{\mathrm{Aa}}$ \\
\hline 1 & $0.000 \pm 0.000^{\mathrm{Aa}}$ & $0.008 \pm 0.002^{\mathrm{Aa}}$ & $0.009 \pm 0.001^{\mathrm{Aa}}$ & $0.010 \pm 0.001^{\mathrm{Aa}}$ & $0.008 \pm 0.001^{\mathrm{Aa}}$ \\
\hline 1.5 & $0.000 \pm 0.000^{\mathrm{Aa}}$ & $0.009 \pm 0.001^{\mathrm{Aa}}$ & $0.009 \pm 0.000^{\mathrm{Aa}}$ & $0.009 \pm 0.001^{\mathrm{Aa}}$ & $0.008 \pm 0.001^{\mathrm{Aa}}$ \\
\hline 2 & $0.000 \pm 0.000^{\mathrm{Aa}}$ & $0.007 \pm 0.001^{\mathrm{Aa}}$ & $0.008 \pm 0.001^{\mathrm{Aa}}$ & $0.007 \pm 0.001^{\mathrm{Aa}}$ & $0.007 \pm 0.001^{\mathrm{Aa}}$ \\
\hline 4 & $0.000 \pm 0.000^{\mathrm{Aa}}$ & $0.008 \pm 0.002^{\mathrm{Aa}}$ & $0.008 \pm 0.002^{\mathrm{Aa}}$ & $0.009 \pm 0.000^{\mathrm{Aa}}$ & $0.008 \pm 0.001^{\mathrm{Aa}}$ \\
\hline
\end{tabular}

${ }_{\mathrm{A}, \mathrm{a}}^{\mathrm{a}}$ : No significant differences were observed within a column and row $(p \geq 0.05)$

antimicrobial activity of phytochemicals on various foodborne pathogens are necessary.

As expected, the $\mathrm{OD}$ values of $L$. monocytogenes were generally higher $(p<0.05)$ in $\mathrm{pH} 7$ than in $\mathrm{pH} 5$ (Tables 16 ). The optical density of $L$. monocytogenes at $\mathrm{pH} 7$ increased $(p<0.05)$ at low concentrations $(0-2 \mu \mathrm{g} / \mathrm{mL})$ of oleanolic acid during incubation for all $\mathrm{NaCl}$ concentrations, but $4 \mu \mathrm{g} / \mathrm{mL}$ of oleanolic acid completely inhibited L. monocytogenes growth at $\mathrm{pH} 7$ (Tables 4-6). Significant effect of $\mathrm{NaCl}$ on strengthening antilisterial effect of oleanolic acid was also observed at $\mathrm{pH}$ 7. In the case of
$\mathrm{pH} 5$, no growth of L. monocytogenes was observed at 6 $\%$ of $\mathrm{NaCl}$ for all oleanolic acid concentrations, but gradual increases of the OD values were observed at $6 \%$ of $\mathrm{NaCl}$ for low levels $(<0.5 \mu \mathrm{g} / \mathrm{mL})$ of oleanolic acid at $\mathrm{pH}$ 7 (Tables 4-6).

The results from this study show that oleanolic acid is still effective to inhibit L. monocytogenes growth even under optimum growth condition for bacterial growth of the pathogen, and the effect of the phytochemical on constraining L. monocytogenes growth is concentrationdependent. Since the conditions used in this study were 
Table 4. Optical density of Listeria monocytogenes ATCC15313 at $600 \mathrm{~nm}$ under sublethal stresses of oleanolic acid and $0 \%$ of $\mathrm{NaCl}$ at pH 7 during incubation at $37^{\circ} \mathrm{C}$ for $48 \mathrm{~h}$

\begin{tabular}{lccccc}
\hline \hline $\begin{array}{c}\text { Oleanolic acid } \\
(\mu \mathrm{g} / \mathrm{mL})\end{array}$ & \multicolumn{5}{c}{ Incubation time $(\mathrm{h})$} \\
\cline { 2 - 6 } & 0 & 6 & 12 & 24 & 48 \\
\hline 0 & $0.000 \pm 0.000^{\mathrm{Ab}}$ & $0.015 \pm 0.002^{\mathrm{Ad}}$ & $0.139 \pm 0.012^{\mathrm{Ac}}$ & $0.307 \pm 0.040^{\mathrm{Aa}}$ & $0.187 \pm 0.012^{\mathrm{Bb}}$ \\
0.25 & $0.000 \pm 0.000^{\mathrm{Ab}}$ & $0.015 \pm 0.002^{\mathrm{Ad}}$ & $0.153 \pm 0.012^{\mathrm{Ac}}$ & $0.286 \pm 0.037^{\mathrm{Bb}}$ & $0.311 \pm 0.337^{\mathrm{Aa}}$ \\
0.5 & $0.000 \pm 0.000^{\mathrm{Ab}}$ & $0.016 \pm 0.002^{\mathrm{Ad}}$ & $0.153 \pm 0.020^{\mathrm{Ac}}$ & $0.249 \pm 0.014^{\mathrm{Ba}}$ & $0.187 \pm 0.023^{\mathrm{Bb}}$ \\
1 & $0.000 \pm 0.000^{\mathrm{Ab}}$ & $0.017 \pm 0.001^{\mathrm{Ad}}$ & $0.159 \pm 0.012^{\mathrm{Aa}}$ & $0.201 \pm 0.040^{\mathrm{Ca}}$ & $0.184 \pm 0.051^{\mathrm{Ba}}$ \\
1.5 & $0.000 \pm 0.000^{\mathrm{Ab}}$ & $0.015 \pm 0.001^{\mathrm{Ad}}$ & $0.029 \pm 0.014^{\mathrm{Ab}}$ & $0.192 \pm 0.036^{\mathrm{Ca}}$ & $0.217 \pm 0.023^{\mathrm{Ba}}$ \\
2 & $0.000 \pm 0.000^{\mathrm{Ab}}$ & $0.012 \pm 0.002^{\mathrm{Ad}}$ & $0.013 \pm 0.001^{\mathrm{Bb}}$ & $0.206 \pm 0.079^{\mathrm{Ca}}$ & $0.223 \pm 0.028^{\mathrm{Ba}}$ \\
4 & $0.000 \pm 0.000^{\mathrm{Ab}}$ & $0.013 \pm 0.002^{\mathrm{Aab}}$ & $0.015 \pm 0.001^{\mathrm{Bab}}$ & $0.015 \pm 0.001^{\mathrm{Da}}$ & $0.057 \pm 0.091^{\mathrm{Ca}}$ \\
\hline
\end{tabular}

A-C: Means within a column with different superscripts are significantly different $(p<0.05)$

${ }^{\mathrm{a}-\mathrm{d}}$ : Means within a row with different superscripts are significantly different $(p<0.05)$

Table 5. Optical density of Listeria monocytogenes ATCC15313 at $600 \mathrm{~nm}$ under sublethal stresses of oleanolic acid and $3 \%$ of $\mathrm{NaCl}$ at $\mathrm{pH} 7$ during incubation at $37^{\circ} \mathrm{C}$ for $48 \mathrm{~h}$

\begin{tabular}{lccccc}
\hline \hline $\begin{array}{c}\text { Oleanolic acid } \\
(\mu \mathrm{g} / \mathrm{mL})\end{array}$ & \multicolumn{5}{c}{ Incubation time $(\mathrm{h})$} \\
\cline { 2 - 6 } & 0 & 6 & 12 & 24 & 48 \\
\hline 0 & $0.000 \pm 0.000^{\mathrm{Ac}}$ & $0.013 \pm 0.002^{\mathrm{Ac}}$ & $0.027 \pm 0.010^{\mathrm{Ab}}$ & $0.254 \pm 0.045^{\mathrm{Aa}}$ & $0.277 \pm 0.026^{\mathrm{Ca}}$ \\
0.25 & $0.000 \pm 0.000^{\mathrm{Ab}}$ & $0.014 \pm 0.002^{\mathrm{Ab}}$ & $0.031 \pm 0.012^{\mathrm{Ab}}$ & $0.213 \pm 0.031^{\mathrm{Ba}}$ & $0.232 \pm 0.022^{\mathrm{Ba}}$ \\
0.5 & $0.000 \pm 0.000^{\mathrm{Ab}}$ & $0.015 \pm 0.002^{\mathrm{Ab}}$ & $0.062 \pm 0.026^{\mathrm{Ab}}$ & $0.271 \pm 0.057^{\mathrm{Aa}}$ & $0.236 \pm 0.019^{\mathrm{Ba}}$ \\
1 & $0.000 \pm 0.000^{\mathrm{Ab}}$ & $0.015 \pm 0.001^{\mathrm{Ab}}$ & $0.035 \pm 0.004^{\mathrm{Ab}}$ & $0.220 \pm 0.090^{\mathrm{Ba}}$ & $0.184 \pm 0.019^{\mathrm{Ba}}$ \\
1.5 & $0.000 \pm 0.000^{\mathrm{Ab}}$ & $0.016 \pm 0.001^{\mathrm{Ab}}$ & $0.017 \pm 0.001^{\mathrm{Ab}}$ & $0.180 \pm 0.106^{\mathrm{Ba}}$ & $0.218 \pm 0.026^{\mathrm{Aa}}$ \\
2 & $0.000 \pm 0.000^{\mathrm{Ab}}$ & $0.013 \pm 0.001^{\mathrm{Ab}}$ & $0.014 \pm 0.001^{\mathrm{Ab}}$ & $0.018 \pm 0.005^{\mathrm{Cb}}$ & $0.185 \pm 0.044^{\mathrm{Aa}}$ \\
4 & $0.000 \pm 0.000^{\mathrm{Aa}}$ & $0.013 \pm 0.001^{\mathrm{Aa}}$ & $0.014 \pm 0.001^{\mathrm{Aa}}$ & $0.014 \pm 0.001^{\mathrm{Ca}}$ & $0.014 \pm 0.005^{\mathrm{Aa}}$ \\
\hline
\end{tabular}

$\overline{\mathrm{A}-\mathrm{C}}$ : Means within a column with different superscripts are significantly different $(p<0.05)$

${ }^{\mathrm{a}-\mathrm{c}}$ : Means within a row with different superscripts are significantly different $(p<0.05)$

Table 6. Optical density of Listeria monocytogenes ATCC15313 at $600 \mathrm{~nm}$ under sublethal stresses of oleanolic acid and $6 \%$ of $\mathrm{NaCl}$ at pH 7 during incubation at $37^{\circ} \mathrm{C}$ for $48 \mathrm{~h}$

\begin{tabular}{|c|c|c|c|c|c|}
\hline \multirow{2}{*}{$\begin{array}{l}\text { Oleanolic acid } \\
\qquad(\mu \mathrm{g} / \mathrm{mL})\end{array}$} & \multicolumn{5}{|c|}{ Incubation time (h) } \\
\hline & 0 & 6 & 12 & 24 & 48 \\
\hline 0 & $0.000 \pm 0.000^{\mathrm{Aa}}$ & $0.014 \pm 0.002^{\mathrm{Ab}}$ & $0.014 \pm 0.001^{\mathrm{Ab}}$ & $0.015 \pm 0.001^{\mathrm{Ab}}$ & $0.138 \pm 0.061^{\mathrm{Ba}}$ \\
\hline 0.25 & $0.000 \pm 0.000^{\mathrm{Aa}}$ & $0.013 \pm 0.001^{\mathrm{Ab}}$ & $0.015 \pm 0.001^{\mathrm{Ab}}$ & $0.014 \pm 0.002^{\mathrm{Ab}}$ & $0.111 \pm 0.060^{\mathrm{Ba}}$ \\
\hline 0.5 & $0.000 \pm 0.000^{\mathrm{Aa}}$ & $0.014 \pm 0.002^{\mathrm{Ab}}$ & $0.014 \pm 0.002^{\mathrm{Ab}}$ & $0.016 \pm 0.001^{\mathrm{Ab}}$ & $0.182 \pm 0.094^{\mathrm{Aa}}$ \\
\hline 1 & $0.000 \pm 0.000^{\mathrm{Aa}}$ & $0.015 \pm 0.002^{\mathrm{Aa}}$ & $0.015 \pm 0.002^{\mathrm{Aa}}$ & $0.016 \pm 0.001^{\mathrm{Aa}}$ & $0.033 \pm 0.017^{\mathrm{Ca}}$ \\
\hline 1.5 & $0.000 \pm 0.000^{\mathrm{Aa}}$ & $0.016 \pm 0.001^{\mathrm{Aa}}$ & $0.016 \pm 0.001^{\mathrm{Aa}}$ & $0.015 \pm 0.001^{\mathrm{Aa}}$ & $0.013 \pm 0.001^{\mathrm{Ca}}$ \\
\hline 2 & $0.000 \pm 0.000^{\mathrm{Aa}}$ & $0.013 \pm 0.002^{\mathrm{Aa}}$ & $0.014 \pm 0.001^{\mathrm{Aa}}$ & $0.013 \pm 0.001^{\mathrm{Aa}}$ & $0.012 \pm 0.001^{\mathrm{Ca}}$ \\
\hline 4 & $0.000 \pm 0.000^{\mathrm{Aa}}$ & $0.015 \pm 0.001^{\mathrm{Aa}}$ & $0.015 \pm 0.002^{\mathrm{Aa}}$ & $0.016 \pm 0.001^{\mathrm{Aa}}$ & $0.013 \pm 0.001^{\mathrm{Ca}}$ \\
\hline
\end{tabular}

$\overline{\mathrm{A}-\mathrm{C}}$ : Means within a column with different superscripts are significantly different $(p<0.05)$

${ }^{\mathrm{a}-\mathrm{b}}$ : Means within a row with different superscripts are significantly different $(p<0.05)$

optimum growth condition for L. monocytogenes, the antilisterial effect of oleanolic acid should be more obvious and minimal inhibition concentration to L. monocytogenes should be lower in ready-to-eat food related conditions such as low storage temperature, high concentration of $\mathrm{NaCl}$, and presence of other antimicrobials. Moreover, use of phytochemical, which is plant-originated such as oleanolic acid, as an antilisterial additive may improve consumer acceptance than bacteria-originated antimicrobials or synthetic chemicals because cus- tomers believe that phytochemicals are safer than synthetic antimicrobials and they have additional bioactivities such as a decreased risk of cancer and other chronic diseases as well as antimicrobial activity (Surles et al., 2004; Feng et al., 2010). Therefore, use of oleanolic acid in the formulation of ready-to-eat meat and poultry products may decrease bacterial populations of $L$. monocytogenes in the products without compromising consumer acceptance.

In conclusion, use of oleanolic acid should be useful in 
inhibiting L. monocytogenes growth, and thus development of the formulations including oleanolic acid is necessary to control the pathogen in ready-to-eat meat and poultry products.

\section{Acknowledgements}

This paper was supported by Wonkwang University in 2009.

\section{References}

1. Banno, N., Akihisa, T., Tokuda, H., Yasukawa, K., Higashihara, H., Ukiya, M., Watanabe, K., Kimmura, Y., Hasegawa, J., and Nishino, H. (2004) Triterpene acids from the leaves of Perilla frutescens and their anti-inflammatory and antitumor-promoting effects. Biosci. Biotech. Biochem. 68, 85-90.

2. Cunha, W. R., Martins, C., Da Silva Ferreira, D., Crotti, A. E., Lopes, N. P., and Albuquerque, S. (2003) In vitro tryppanocidal activity of triterpenes from Milconia species. Planta Med. 69, 470-472.

3. Farber, J. M. and Peterkin, P. I. (1991) Listeria monocytogenes, a food-borne pathogen. Microbiol. Rev. 55, 476-511.

4. Feng, S., Zeng, W., Luo, F., Zhao, J., Yang, Z., and Sun, Q. (2010) Antibacterial activity of organic acids in aqueous extracts from pine needles (Pinus massoniana Lamb.). Food Sci. Biotechnol. 19, 35-41.

5. Glass, K. A. and M. P. Doyle. (1989) Fate of Listeria monocytogenes in processed meat products during refrigerated storage. Appl. Environ. Microbiol. 55, 1565-1569.

6. Horiuchi, K., Sumiko, S., Hantano, T., Yoshida, T., Kuroda, T., and Tsuchiya, T. (2007) Antimicrobial activity of oleanolic acid from Salvia officinalis and related compounds on vancomycin-resistant Enterococci (VRE). Biol. Pharm. Bull. 30, 1147-1149.

7. Isalm, B., Khan, S. N., Haque, I., Alam, M., Mushfiq, M., and Khan, A. U. (2008) Novel anti-adherence activity of mulberry leaves: inhibition of Streptococcus mutans biofilm by 1deoxynojirimycin isolated from Morus alba. J. Antimicrob. Chemother. 62, 751-757.

8. Jimenez-Arellances, A., Meckes, M., Torres, J., and LunaHerrera, J. (2007) Antimycobacterial triterpenoids from Lantana hispida (Verbenacease). J. Ethnopharmacol. 111, 202-205.

9. Kurek, A., Grudniak, A. M., Szwed, M., Klicka, A., Samluk, L., Wolska, K. I., Janiszowska, W., and Popowska, M. (2010) Oleanolic acid and ursolic acid affect peptidoglycan metabolism in Listeria monocytogenes. Antonie van Leeuwenhoek. 97, 61-68.

10. Lee, S. H., Chang, K. S., Su, M. S., Huang, Y. S., and Jang, H. D. (2007) Effects of some Chinese medicinal plant extracts on five different fungi. Food Control. 18, 1547-1554.

11. Liu, J. (1995) Pharmacology of oleanolic acid and ursolic acid. J. Ethnopharm. 49, 57-68.
12. Mbandi, E. and L. A. Shelef. (2002) Enhanced antimicrobial effects of combination of lactate and diacetate on Listeria monocytogenes and Salmonella spp. in beef bologna. Int. J. Food Microbiol. 76, 191-198.

13. Mead, P. S., L. Slutsker, V. Dietz, L. F. McCaig, J. S. Bresee, C. Shapiro, P. M. Griffin, and R. V. Tauxe. (1999) Foodrelated illness and death in the United States. Emerg. Infect. Dis. 5, 607-625.

14. Ngouela, S., Ndjakou, B. L., Tchamo, D. N., Zelefack, F., Tsamo, E., and Connolly, J. D. (2005) A prenylated xanthone with antimicrobial activity from the seeds of Symphonia globulifera. Nat. Prod. Res. 19, 23-27.

15. Nuñez de Gonzalez, M. T., Keeton, J. T., Acuff, G. R., Ringer, L. J., and Lucia, L. M. (2004) Effectiveness of acidic calcium sulfate with propionic and lactic acid and lactates as postprocessing dipping solutions to control Listeria monocytogenes on frankfurters with or without potassium lactate and stored vacuum packaged at $4.5^{\circ} \mathrm{C}$. J. Food Prot. 67, 915-921.

16. Oh, S-H., Kim, J-H., Lee, J-W., Lee, Y-S., Park, K-S., Kim, J-G., Lee, H-K, and Byun, M-W. (2004) Effect of combined treatment of gamma irradiation and addition of rosemary extract powder on ready-to-eat hamburger steaks: I. microbiological quality and shelf-life. J. Korean Soc. Food Sci. Nutr. 33, 687-693.

17. Ovesna, Z., Vachalkova, A., Horvathova, K., and Tothova, D. (2004) Pentacyclic triterpenoic acids: new chemoprotective compounds. Minireview. Neoplasma. 51, 327-333.

18. Ros, J. L. and Recio, M. C. (2005) Medicinal plants and antimicrobial activity. J. Ethnopharmacol. 100, 80-84.

19. Somova, L. O., Nadar, A., Rammanan, P., and Shode, F. O. (2003) Cardiovascular, antihyperlipidemic and antioxidant effects of oleanolic and ursolic acids in experimental hypertension. Phytomedicine. 10, 115-121.

20. Surles, R. L., Weng, N., Simon, P. W., Tanumihardjo, S. A. (2004) Carotenoid profiles and consumer sensory evaluation of specialty carrots (Daucus carota, L.) of various colors. Agri. Food Chem. 52, 3417-3421.

21. Tassou, C., Koutsoumanis, K., and Nychas, G. J. E. (2000) Inhibition of Salmonella enteritidis and Staphylococcus aureus in nutrient broth by mint essential oil. Food Res. Int. 33, 273-280.

22. Torres-Santos, E. C., Lopes, D., Oliveira, R. R., Carauta, J. P., Falcao, C. A., Kaplan, M. A., and Rossi-Bergmann, B. (2004) Antileishmanial activity of isolated triterpenoids from Pourouma guidanensis. Phytomedicine. 11, 114-120.

23. Valero, M. and Salmeron, M. C. (2003) Antibacterial activity of 11 essential oils against Bacillus cereus in tyndallized carrot broth. Int. J. Food Microbiol. 85, 73-81.

24. Vazquez-Bolland, J. A., Kuhn, M., Berche, P., Chakraborty, T., Dominquez-Bernal, G., Goebel, W., Gonzalez-Zorn, B., Wehland, J., and Kreft, J. (2001) Listeria pathogenesis and molecular virulence determinants. Clin. Microbiol. Rev. 14, 584-640.

(Received 2010.3.22/Revised 2010.5.26/Accepted 2010.5.27) 